\title{
Efek Implementasi Tgfu (Teaching Game For Understanding) Terhadap Peningkatan Keterampilan Bermain Bolavoli
}

\author{
Aba Sandi Prayoga \\ Program Studi Pendidikan Jasmani Kesehatan dan Rekreasi, STKIP Modern Ngawi \\ adamhamis79@gmail.com \\ Andri Arif Kustiawan \\ Program Studi Pendidikan Jasmani Kesehatan dan Rekreasi, STKIP Modern Ngawi \\ andrigww3m@gmail.com
}

\begin{abstract}
Abstrak
Tujuan penelitian ini adalah untuk mengetahui 1. Keefektifan aplikasi implementasi Teaching Game for Understanding (TGfU) dalam mengajarkan keterampilan bermain bolavoli. 2. Membandingkan implementasi Teaching Game for Understanding (TGfU) dengan pembelajaran Konvensional terhadap peningkatan keterampilan bermain bolavoli pada siswa kelas X SMK Modern Ngawi. Penelitian ini merupakan penelitian eksperimen kuasi (PEK). Penelitian dilaksanakan dengan desain Pretest-Postest NonEquivalent Control Group. Subjek penelitian adalah siswa kelas X SMK Modern Ngawi yang berjumlah 40 siswa. Dalam penelitian ini terdapat dua kelompok, yaitu kelompok kontrol sebanyak 20 siswa dan kelompok eksperimen sebanyak 20 siswa. Teknik pengumpulan data dengan tes keterampilan bolavoli Strand and Wilson. (1993: 136-141), tes membuat keputusan taktik dan pelaksanaan keterampilan yaitu dengan GPAI (Game Performance Assesment Instrument) dan lembar observasi atau lembar pengamatan. Berdasarkan hasil penelitian menunjukkan sebagai berikut: (1) Dari analisis perbandingan ketuntasan belajar untuk hasil skor posttest dalam kelompok eksperimen ada 18 siswa yang tuntas, sedangkan dalam kelompok kontrol hanya ada 14 siswa dari 20 siswa. Dengan demikian maka TGfU efektif untuk membelajarkan keterampilan bermain bolavoli. Dari segi produk, atau peningkatan keterampilan bermain bolavoli juga menunjukan bahwa pembelajaran bolavoli dengan penerapan TGfU lebih baik dari pada secara konvensional. Berdasarkan hasil uji kesamaan dan uji kesejajaran ternyata dua model regresi linier tidak sama, namun sejajar. Oleh karena itu dapat disimpulkan bahwa ada perbedaan hasil peningkatan keterampilan bermain bolavoli antara pendekatan TGfU dengan pendekatan konvensional. Dari ratarata hasil tes akhir siswa yang belajar dengan pendekatan TGfU adalah 163 sedangkan rata-rata test akhir siswa yang belajar dengan pendekatan konvensional adalah 159. Hal ini menunjukkan bahwa hasil peningkatan keterampilan bermain bolavoli dengan pendekatan TGfU lebih baik dibanding pendekatan konvensional.
\end{abstract}

\section{Kata Kunci: penerapan TGfU, keterampilan bermain bolavoli}

\section{PENDAHULUAN}

Bolavoli merupakan salah satu cabang olahraga permainan yang diajarkan dalam pendidikan jasmani. Permainan bolavoli tersebut diajarkan dari tingkat SD, SMP dan SMA/SMK. Oleh karena itu permainan bolavoli yang diajarkan di masing-masing sekolah berbeda-beda. Perbedaan itu tanpak dari jenis metode pembelajaranya. Salah satunya pembelajaran di sekolah SMK Modern Ngawi. Dari beberapa teknik dasar dalam permainan bolavoli yang diberikan di sekolah tersebut dari mengenai teknikdasar servis, passing, block dan smash. Maka 
setiap siswa harus bisa melakukan teknik dasar yang ada dalam permainan bolavoli tersebut, Karena pada dasarnya teknik dasar tersebut merupakan syarat dalam untuk bisa menjalankan permainan bolavoli. Selain itu karena permainan bolavoli merupakan materi pokok yang harus ditempuh oleh seorang siswa.

Dari hasil observasi dan wawancara di SMK Modern Ngawi diketahui bahwa pelaksanaannya sudah berjalan sesuai dengan rencana pembelajaran dari guru. Namun dalam pembelajaran bolavoli di SMK Modern Ngawi tersebut belum menunjukkan hasil yang diharapkan.Hasil belajar bolavoli tersebut meliputi servis bawah,servis atas, passing bawah, passing atas, mengeblockdan smash normal. Dari 30 siswa hanya 12 siswa yang dinyatakan mencapai target, artinya bahwa hanya sekitar 52\% siswa yang dinyatakan tuntas dalam pembelajaran. Hal ini dapat dibuktikan pada saat siswa melakukan pembelajaran bolavoli masih ada siswa yang mengalami kesulitan. Kesulitan yang dihadapi para siswa yaitu pada saat servis bawah kebanyakan bola tidak bisa melampaui net bahkan bola tidak berhasil mengenai sasaran di kawasan lapangan lawan. Sedangkan pada saat passing bawah arah bola masih tidak beraturan, saat passing atas kebanyakan bola tidak bisa melambung tinggi dan pada saat smash kebanyakan tangan yang melakukan masih menyentuh net. Dengan minimnya kemampuan siswa dalam bermain bolavoli diatas, sehingga berdampak pada hasil belajar bolavoli yang kurang memuaskan.

Penerapan pembelajaran bolavoli yang diajarkan di SMK Modern Ngawi masih menggunakan pendekatan pembelajaran konvensional atau tradisional. Artinya bahwa pembelajaran tersebut masih berpusat pada guru (Teacher Centered), kurangnya kebebasan seorang murid dalam mengeksplorasikan kemampuannya serta pembelajaran yang dilakukan dengan berulang-ulang dan sering kali siswa harus lama menunggu giliran untuk melakukan. Sehingga hal ini berdampak pada munculnya emosional siswa yaitu rasa bosan dan disertai dengan ketidakseriusan untuk melakukan kegiatan pembelajaran. Padahal untuk anak tingkat usia SMK (Sekolah Menengah Kejuruan) merupakan masa peralihan dari anak-anak ke dewasa sehingga tingkat usia anak SMK khususnya kelas X, masih didominasi oleh masa bermain (siswa tertarik pada permainan) sehingga guru harus menyesuaikan dengan usia perkembangan siswa.

Mendesain, mengemas dan memberikan penyajian pembelajaran bolavoli yang menarik, praktis dan diminati siswa adalah tugas utama seorang guru. Oleh karena itu guru harus mampu menyesuaikan dan menganalisis karakteristik yang berhubungan dengan siswa dan materi pembelajaran tersebut. Guru juga harus mampu menerapkan model, metode dan strategi yang sesuai dengan materi pembelajaran yang akan disampaikan. Kebanyakan pada anak usia SMK mereka masih ingin mencari jati dirinya sendiri. Mereka mencari sesuatu yang baru, termasuk didalamnya dalam pembelajaran bolavoli.

Banyaknya model pembelajaran yang mengharuskan seorang guru penjas untuk selalu mengikuti perkembangan dan kemajuan model-model pembelajaran. Namun pada kenyataannya masih banyak guru yang belum memahami dan mengetahui tentang model pembelajaran yang ada dan tengah berkembang saat ini. Padahal dengan mengikuti perkembangan pembelajaran yang ada, maka seorang guru akan memiliki alternatif untuk menyelesaikan permasalahan yang ada. 
Salah satu model pembelajaran yang akhir-akhir ini baru marak diperbincangkan adalah model pembelajaran Kooperatif. Inti dari pembelajaran kooperatif itu sendiri adalah dimana siswa bekerja dalam kelompok-kelompok kecil untuk saling membantu satu sama lainnya dalam mempelajari materi pelajaran. Sedangkan dalam penerapannya pembelajaran kooperatif itu terdiri dari berbagai macam tipe. Salah satunya adalah tipeTeaching Game for Understanding (TGfU).

Teaching Game for Understanding (TGfU) merupakan suatu konsep pengajaran dan pembelajaran yang dihasilkan oleh David Bunker dan Rod Thorpe pada tahun 1982 di University Loughboroungh. Teaching Game for Understanding (TGfU) merupakan suatu pengajaran permainaan untuk kefahaman yang dapat menarik minat dan perhatian anak-anak di dalam atau di luar sekolah supaya mereka tidak merasa bosan. (Buku Kaedah Mengajar Pendidikan Jasmani yang ditulis oleh Mohd Sofian Omar Fauzee)

Teaching Game for Understanding (TGfU) merupakan sebuah konsep pembelajaran yang lebih berfokus terhadap pemahaman yang meyeluruh pada setiap permainan. Murid-murid dapat memahami sesuatu prinsip atau konsep dalam permainan tertentu. Teaching Game for Understanding (TGfU) juga menekankan kepada peningkatan tahap aktivitas fisikal. Waktu Pendidikan Jasmani dan Kesehatan di dalam sekolah rendah dan sekolah menengah hendaklah selalu menjalankan Teaching Game for Understanding (TGfU) supaya pelajar-pelajar dapat efisien dalam aktivitas fisikal. Teaching Game for Understanding (TGfU) juga menjadikan kelas Pendidikan Jasmani sebagai tempat dan masa yang sesuai untuk persaingan, motivasi serta bersuka ria. Guru hendaknya memastikan persaingan ini dijalankan dengan sehat dan menjalankan permainan yang dapat mengeratkan hubungan persahabatan dan kerjasama di antara pelajar.

Melalui pendekatan pembelajaran Teaching Game for Understanding (TGfU) suatu pendidikan jasmani untuk memperkenalkan bagaimana anak mengerti olahraga melalui bentuk konsep dasar bermain. Teaching Game for Understanding (TGfU) tidak memfokuskan pembelajaran pada teknik bermain olahraga sehingga pembelajaran akan lebih dinamis dan sesuai dengan tahap perkembangan anak. Melalui pendekatan Teaching Game for Understanding (TGfU) pembelajaran pendidikan jasmani menjadi tidak membosankan bagi siswa. Pendekatan Pembelajaran Teaching Game for Understanding (TGfU) lebih menekankan pada pendekatan taktik tanpa mempedulikan teknik yang digunakan, bermain dalam segala posisi dalam permainan, mengembangakan kreativitas bermain, kecepatan pengambilan keputusan dalam permainan dan menekankan berbagai macam variasi bermain. Pendekatan pembelajaran ini cocok untuk berbagai tingkatan anak sekolah. Pendekatan ini akan memicu perubahan paradigma pembelajaran yang bermuara pada peningkatan kualitas pendidikan jasmani sehingga tujuan pendidikan jasmani yang mencakup ranah kognitif, afektif, dan psikomotor dapat tercapai.

Dari latar belakang tersebut maka perlu diadakan penelitian yang mendalam untuk mengetahui implementasi pembelajaran Kooperatif tipe Teaching Game for Understanding (TGfU) sebagai salah satu alternatif dalam permasalahan pembelajaran passing bawah, passing atas, servis normal, smash, dan mengeblock dalam permainan bolavoli. Hal tersebut akan dilaksanakan dengan menggunakan penelitian jenis Penelitian Eksperimen Kuasi (PEK). PEK ini dilakukan 
dengan membandingkan penerapan pembelajaran Kooperatif tipe Teaching Game for Understanding (TGfU) dengan penerapan pembelajaran Konvensional, hal itu dilakukan sebagai upaya meningkatkan keberhasilan dalam pembelajaran keterampilan bermain bolavoli di SMK Modern Ngawi khususnya pada kelas $\mathrm{X}$.

\section{METODE}

Subyek penelitian ini adalah siswa kelas X SMK Modern Ngawi Tahun Pelajaran 2019/ 2020.

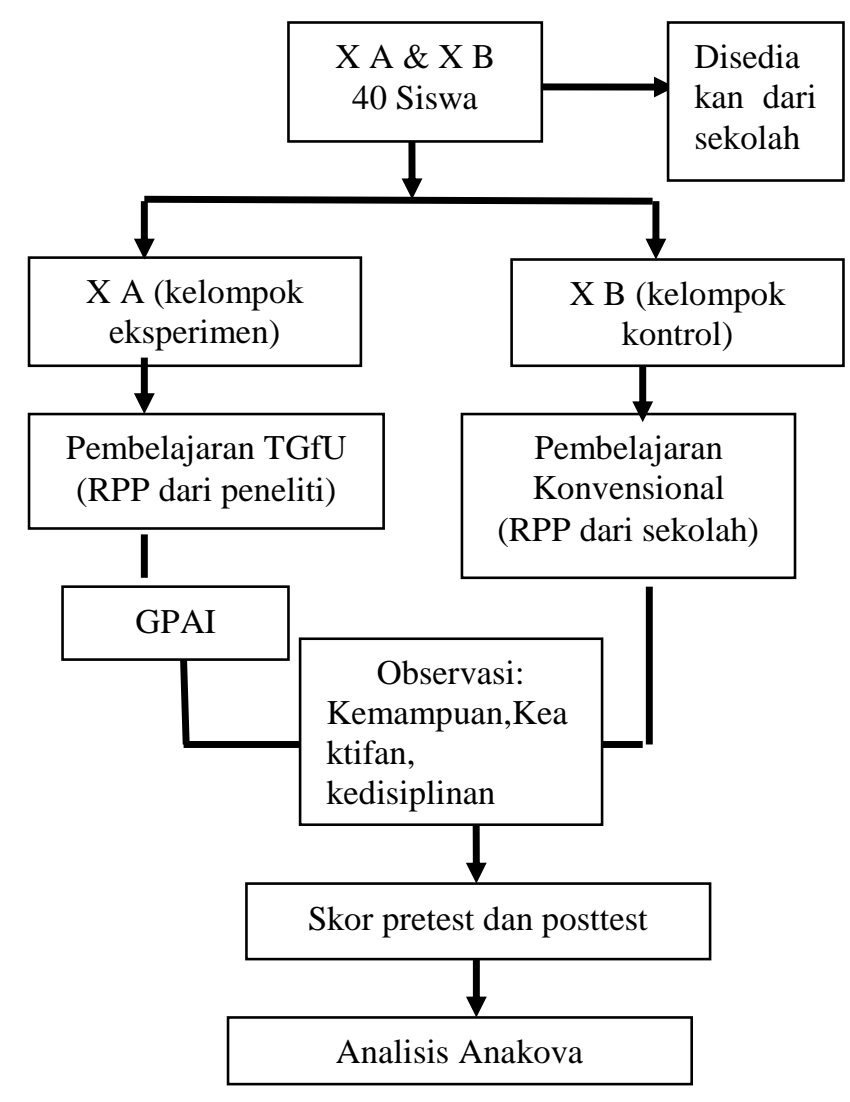

Gambar. Bagan Subjek Penelitian

Jenis penelitian yang digunakan adalah Penelitian Eksperimen Kuasi (PEK). Penelitian Eksperimen Kuasi (PEK) ini dilaksanakan dengan desain Pretest-Postest Non-Equivalent Control Group. Desain ini terdiri atas satu kelompok eksperimen dan satu kelompok kontrol. Ilustrasi desain PEK yang dituju tergambar sebagai berikut:

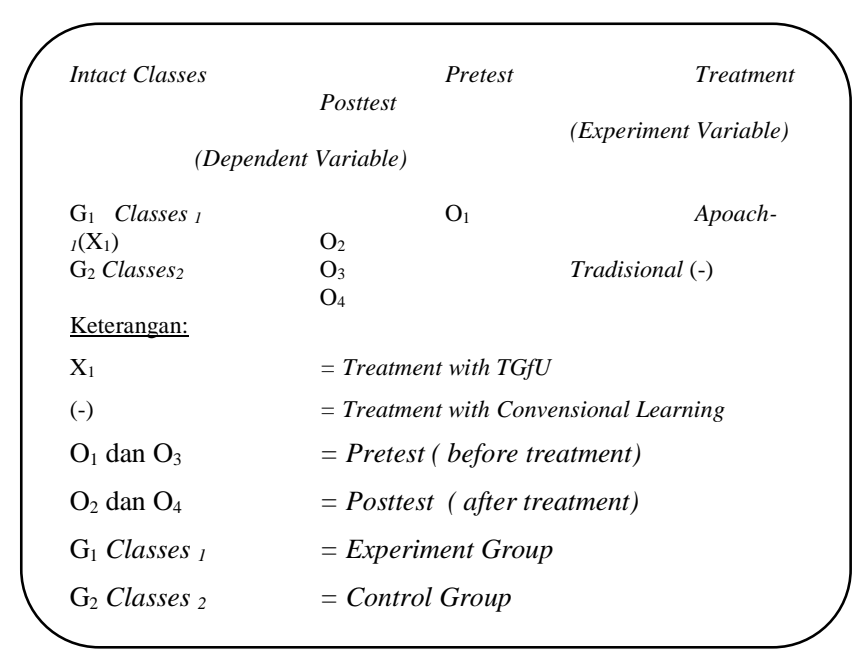

Data yang harus dikumpulkan adalah kemampuan bermain bolavoli, termasuk juga data aktivitas siswa dalam mengikuti pembelajaran. Instrument penelitian yang digunakan berupa tes keterampilan bolavolidari Strand and Wilson. (1993: 136-141), tes membuat keputusan taktik dan pelaksanaan keterampilan yaitu dengan GPAI (Game Performance Assesment Instrument) dan lembar observasi atau lembar pengamatan. Data aktivitas siswa dalam mengikuti pembelajaran diperoleh melalui observasi. Untuk mendapatkannya pengamat menggunakan lembar observasi pengelolaan pembelajaran selama pembelajaran berlangsung. Siswa diamati berdasarkan petunjuk yang ditetapkan dalam lembar observasi.

Data yang terkumpul selanjutnya dikelompokkan, dikalkulasi dan dianalisis menurut masalah dan tujuan analisis. Atas dasar permasalahan dalam PEK ini, maka selanjutnya dikelompokkan ke dalam dua tujuan, yakni :

1. Untuk kepentingan penilaian proses analisis deskriptif.

2. Untuk kepentingan penilaian hasil analisis inferensial.

Terkait dengan kedua tujuan tersebut khususnya untuk kepentingan analisis data, maka analisis dikelompokkan ke dalam empat tujuan, yakni untuk :

1. Uji reliabilitas intrakelas 
2. Uji prasyarat analisis/normalitas, homogenitas, linieritas,

3. Uji anakova

4. Penyusunan norma/standar dalam skala liniear.

Untuk memaknai data secara menyeluruh, maka analisis data dilakukan dengan statistik inferensial yang meliputi statistik parametrik dan nonparametrik.Komputasi analisis data keseluruhan dilakukan dengan mengaplikasikan program SPSS (Statistical Product And Service Solution) versi 17. SPSS merupakan program aplikasi yang digunakan untuk melakukan penghitungan statistik dengan menggunakan komputer. SPSS memberikan berbagai fasilitas perangkuman dan presentasi data dari yang sederhana hingga komplek karena didalamnya terdapat program yang terintegrasi sehingga proses analisis data lebih mudah, efesien dan deskripsi data lebih rinci.

\section{HASIL DAN PEMBAHASAN}

Penelitian Eksperimen Kuasi (PEK) ini berlangsung dari bulan Maret sampai dengan Juni 2020. PEK ini bertujuan untuk melihat keefektifan penerapan TGfU untuk bermain bolavoli. Sebagai subjek penelitian adalah siswa kelas X SMK Modern Ngawi tahun pelajaran 2019/2020. Sebagai kelompok eksperimen (KE) adalah siswa kelas $\mathrm{X}$ yang berjumlah 20 siswa dan kelompok kontrol (KK) adalah siswa kelas $X$ yang berjumlah 20 siswa. Penelitian ini dilaksanakan sebanyak 4 kali pertemuan dengan tingkat kompleksitas atau level-level permainan yang telah ditentukan. Pada pertemuan pertama siswa mendapat materi dalam level I, pada pertemuan kedua mendapat materi dalam level II, pada pertemuan ketiga siswa mendapat materi dalam level III, pada pertemuan keempat siswa mendapat materi dalam level IV, dan pada pertemuan kelima siswa mendapat materi gabungan dari level I sampai IV.
Dari hasil analisis data observasi kegiatan siswa, dapat disimpulkan bahwa kegiatan siswa dalam pembelajaran kelompok eksperimen selama 4 kali pertemuan adalah cukup efektif. Hal ini dapat dilihat pada tabel di bawah ini:

Tabel 4. Hasil Observasi KE

\begin{tabular}{|c|c|c|}
\hline Kategori & Frekuensi & Presentase \\
\hline Baik Sekali & 3 & $15 \%$ \\
\hline Baik & 7 & $35 \%$ \\
\hline Cukup & 10 & $50 \%$ \\
\hline Kurang & - & - \\
\hline
\end{tabular}

Dari tabel di atas, dapat dilihat bahwa sebagian besar siswa termasuk dalam kategori baik yaitu sebanyak 7 siswa atau sebesar 35\%. Siswa dengan kategori baik sekali sebanyak 3 siswa atau sebesar $15 \%$. Siswa dengan kategori cukup sebanyak 10 siswa atau sebesar 50\%. Data observasi pada kelompok kontrol tidak dapat dilaksanakan karena pembelajaran tidak didesain seperti pada kelompok eksperimen sehingga tidak memungkinkan untuk pengambilan data observasi untuk kelompok kontrol.

Dari data hasil peningkatan keterampilan bermain bolavoli saat pretest dan posttest baik pada kelompok eksperimen maupun kelompok kontrol dapat dilihat pada penghitungan statistik deskriptif. Hasil perbandingan secara deskriptif hasil peningkatan keterampilan bermain siswa kelompok eksperimen dan kontrol disajikan pada tabel 7 berikut: 
Tabel 5. Perbandingan Hasil Peningkatan Keterampilan Bermain Bolavoli KE dan KK

\begin{tabular}{|c|c|c|c|c|c|c|}
\hline \multirow{3}{*}{ Kategori } & \multirow{3}{*}{ Nilai } & Frek & ensi & \multirow{3}{*}{ Nilai } & \multirow{2}{*}{\multicolumn{2}{|c|}{$\begin{array}{c}\text { Frekuensi } \\
\text { Posttest }\end{array}$}} \\
\hline & & \multicolumn{2}{|c|}{ Pretest } & & & \\
\hline & & $K K$ & $K E$ & & $K K$ & $K E$ \\
\hline $\begin{array}{l}\text { Baik } \\
\text { Sekali }\end{array}$ & $\begin{array}{c}\geq \\
170\end{array}$ & 1 & 1 & $\begin{array}{c}\geq \\
171\end{array}$ & 1 & 4 \\
\hline Baik & $\begin{array}{l}159- \\
169\end{array}$ & 3 & 3 & $\begin{array}{l}156- \\
170\end{array}$ & 5 & 9 \\
\hline Cukup & $\begin{array}{c}148- \\
158\end{array}$ & 8 & 7 & $\begin{array}{c}139- \\
154\end{array}$ & 8 & 5 \\
\hline Kurang & $\begin{array}{l}137- \\
147\end{array}$ & 3 & 5 & $\begin{array}{l}128- \\
138\end{array}$ & 3 & 1 \\
\hline $\begin{array}{l}\text { Kurang } \\
\text { Sekali }\end{array}$ & $\begin{array}{c}\leq \\
136\end{array}$ & 2 & 2 & $\begin{array}{c}\leq \\
127\end{array}$ & 1 & 1 \\
\hline \multicolumn{2}{|c|}{ Jumlah Tuntas } & 13 & 11 & & 14 & 18 \\
\hline \multicolumn{2}{|c|}{$\%$ Tuntas } & $65 \%$ & $55 \%$ & & $70 \%$ & $90 \%$ \\
\hline \multicolumn{2}{|c|}{$\begin{array}{c}\text { Jumlah Tidak } \\
\text { Tuntas }\end{array}$} & 5 & 7 & & 4 & 2 \\
\hline \multicolumn{2}{|c|}{$\begin{array}{c}\% \text { Tidak } \\
\text { Tuntas }\end{array}$} & $35 \%$ & $45 \%$ & & $30 \%$ & $10 \%$ \\
\hline \multicolumn{2}{|c|}{ Jumlah Siswa } & 20 & 20 & & 20 & 20 \\
\hline
\end{tabular}

Dari data deskriptif diatas dapat dilihat ketuntasan belajar siswa dari pretest dan posttest. Pada KK saat pretest siswa yang tuntas sebanyak 13 siswa atau $65 \%$ setelah mendapatkan perlakuan ketuntasan belajar siswa saat posttest meningkat menjadi 14 siswa atau $70 \%$ dari 20 siswa. Sedangkan pada KE saat pretest siswa yang tuntas sebanyak 11 siswa atau 55\% setelah mendapatkan perlakuan ketuntasan belajar siswa saat posttest meningkat menjadi 18 siswa atau $90 \%$ dari 20 siswa. Dengan demikian pembelajaran secara TGfU lebih efektif dibanding pembelajaran secara konvensional untuk pembelajaran permainan bolavoli.

Pembahasan hasil penelitian ini memberikan interpretasi lebih lanjut, terutama mengenai hasil analisis data yang telah dikemukakan sebelumnya. Pembahasannya sebatas dalam pengertian evaluasi dan tidak atau belum kearah verifikasi suatu teori, karena itu pembahasannya lebih cenderung ke deskripsi empiris atas dasar hasil analisis statistik deskriptif dan inferensial diperoleh dua informasi penting yakni:

1. 1. Dari segi proses, pendekatan TGfU adalah efektif. Keefektifan penerapan pendekatan TGfU seperti ditunjukan oleh hasil-hasil analisis data, a) Analisis data dengan lembar observasi terhadap kegiatan siswa dalam proses pembelajaran selama 4 kali pertemuan, bahwa sebagian besar siswa termasuk dalam kategori baik sebanyak 7 siswa atau 35\%, kategori cukup sebanyak 10 siswa atau $50 \%$ dan baik sekali sebanyak 3 siswa atau 15\%. Dalam pembelajaran konvensional tidak dapat dilaksanakan observasi saat pembelajaran berlangsung, karena pembelajaran tidak terdesain dengan rinci sebagaimana pada kelompok eksperimen. b) Dari analisis perbandingan hasil skor pretest dan posttest, siswa dikatakan tuntas belajarnya apabila berada dalam kategori baik sekali, baik dan cukup. Pada kelompok kontrol saat pretest siswa yang tuntas sebanyak 13 siswa atau $65 \%$ setelah mendapatkan perlakuan (posttest) meningkat menjadi 14 siswa atau $70 \%$ dari 20 siswa. Sedangkan pada kelompok eksperimen saat pretest siswa yang tuntas sebanyak 11 siswa atau $55 \%$ setelah mendapatkan perlakuan (posttest) meningkat menjadi 18 siswa atau $90 \%$ dari 20 siswa. Dalam pelaksanaan pembelajaran dengan pendekatan TGfU lebih variatif, disini juga memanfaatkan media bantu pembelajaran sehingga siswa lebih aktif dan senang dalam mengikuti pembelajaran, sedangkan dalam pembelajaran konvensional pembelajaran bersifat monoton sehingga siswa cepat merasa jenuh dan bosan selama mengikuti pembelajaran. Dengan demikian, pembelajaran dengan pendekatan TGfU dalam pembelajaran permainan bolavoli siswa kelas $X$ SMK Modern Ngawi adalah efektif. 
2. Dari segi produk, atau peningkatan keterampilan bermain bolavoli juga menunjukan bahwa pembelajaran permainan bolavoli dengan pendekatan TGfU lebih baik daripada pendekatan secara konvensional. Berdasarkan hasil uji kesamaan dan uji kesejajaran ternyata dua model regresi linier tidak sama, namun sejajar. Oleh karena itu dapat disimpulkan bahwa ada perbedaan hasil peningkatan keterampilan bermain bolavoli antara pendekatan TGfU dengan pendekatan konvensional. Konstanta garis regresi kelompok eksperimen adalah 16.564 . Konstanta ini lebih besar dari konstanta garis regresi kelompok kontrol yaitu 14.723. Secara geometris garis regresi kelompok eksperimen diatas garis regresi kelompok kontrol. Dari rata-rata hasil tes akhir siswa yang belajar dengan pendekatan TGfU adalah 163 sedangkan rata-rata test akhir siswa yang belajar dengan pendekatan konvensional adalah 159. Hal ini menunjukkan bahwa hasil peningkatan keterampilan bermain bolavoli dengan pendekatan TGfU lebih baik dibanding hasil peningkatan keterampilan bermain bolavoli dengan pendekatan konvensional.

Meski hipotesis hasil penelitian teruji, namun dalam pelaksanaan penelitian eksperimen kuasi ini ada beberapa kelemahan, antara lain: (1) Observasi terhadap kegiatan siswa kurang maksimal karena hanya dilakukan pada kelompok eksperimen saja dan terbatasnya observer, observasi pada KK tidak dapat dilaksanakan karena dalam KK pembelajaran tidak terdesain dengan rinci sebagaimana pada KE. (2) Dalam ketuntasan belajar, kriteria penilaiannya dibuat oleh peneliti sendiri dengan memodifikasi dari modul evaluasi.

\section{PENUTUP}

\section{Simpulan}

Sesuai dengan deskripsi sajian analisis data dan pembahasannya, maka dapat ditarik simpulan penelitian sebagai berikut:

Efek Penerapan TGfU efektif untuk meningkatkan keterampilan bermain bolavoli pada siswa kelas X SMK Modern Ngawi tahun pelajaran 2019/2020. Keefektifan penerapan TGfU seperti ditunjukan oleh hasil analisis data observasi terhadap kegiatan siswa dalam pembelajaran selama 4 kali pertemuan sebagian besar siswa termasuk dalam kategori baik sebanyak 7 siswa atau 35\%, kategori cukup sebanyak 10 siswa atau $50 \%$ dan baik sekali sebanyak 3 siswa atau $15 \%$, sedangkan dilihat dari peningkatan hasil belajar siswa yang belajar dengan efek penerapan TGfU ketuntasan belajar siswanya meningkat dari 11 menjadi 18 siswa dan untuk pembelajaran konvensional ketuntasan belajar siswanya meningkat dari 13 menjadi 14 siswa dari 20 siswa.

Hasil peningkatan keterampilan bolavoli siswa yang belajar dengan pendekatan TGfU lebih baik dari pada siswa yang belajar dengan pendekatan konvensional. Dari ratarata hasil tes akhir siswa yang belajar dengan pendekatan TGfU adalah 163 sedangkan rata-rata test akhir siswa yang belajar dengan pendekatan konvensional adalah 159.

\section{Saran}

Pada penelitian ini agar hasil lebih maksimal bisa menggunakan sampel yang lebih banyak dan untuk kelanjutan dari penelitian ini bisa dibuatkan sebuah video pembelajaran dalam penggunaan TGfU.

Diharapkan pada sekolah-sekolah dapat menggunakan TGfU sebagai metode pembelajaran bola voli bahkan juga dapat 
digunakan untuk pembelajaran olahraga yang lainnya.

\section{DAFTAR PUSTAKA}

Achper Conference. (2010, 25 November). Using Game Sense in the Curriculum. Diakses 2 Juni 2012, dari http://www.achper.vic.edu.au/ sitebuilder/resources/knowledge/asset/f iles/33/gamesenseinthecurriculumwork shopnotesnov2010.pdf.

Depdikbud. (2001). Kamus Besar Bahasa Indonesia. Jakarta: Balai Pustaka.

Dimyati \& Mudjiono. (1999). Belajar Dan Pembelajaran. Jakarta: Depdikbud.

Joy, I. B \& Barbara, J. M. (2005). "Teaching Games for Understanding: As aCurriculum Model". In Griffin \& J. Butler (Eds.), Teaching Games for Understanding: Theory, Research, and Practice. Windsor: Human Kinetics

Ma'mun, A.\& Subroto, T. (2001). Pendekatan Keterampilan Taktis dalam Pembelajaran Bolavoli. Jakarta: Direktorat Jendral Olahraga.

Memmert, D.\& Harvey, S. (2008). The Game Perfomance Assessment Instrument. Journal of Teachingin Physica Education, 27, 220-240

Pribadi, B.A. (2011). Model Desain Sistem Pembelajaran. Jakarta: Dian Rakyat.

Roji, (2007). Pendidikan Jasmani Olahraga dan Kesehatan untuk SMP kelas VII. Jakarta: Erlangga

Sarwono. 2008. Aplikasi Model Pembelajaran Kooperatif Pada Mata Kuliah Biomekanika Olahraga di Program Studi PJKR JPOK FKIP UNS. Laporan Penelitian. (tidak diterbitkan). Surakarta: FKIP UNS.

Saryono \& Nopembri, S. (2009). Gagasan dan Konsep Dasar Teaching Game for Understanding (TGfU). Yogyakarta: Fakultas Ilmu Keolahragaan UNY

Sunardi \& Kardiyanto, D. W. (2013). Bolavoli. Surakarta: UPT Penerbitan dan Percetakan UNS (UNS Press)

Tarigan. (2001). Pendekatan Keterampilan Taktis dalam Pembelajaran Sepak Bola. Jakarta: Depdiknas.
Wibowo, I. (2012). "Peningkatan Hasil Belajar Passing Bawah Bolavoli Dengan Penerapan Model Cooperative Learning Pada Siswa Kelas X Tata Busana B SMK Negeri 9 Surakarta Semester Genap Tahun Pembelajaran 2011/2012”. FKIP UNS: Belum diterbitkan. 